\title{
THE SEA FACTOR IN THE SPATIAL AND SOCIO-ECONOMIC DYNAMICS OF TODAY'S RUSSIA
}

\author{
AleXANDER DruZHININ ${ }^{1}$ \\ South Federal University, Rostov-on-Don \\ Immanuel Kant Baltic Federal University, Kaliningrad, Russia \\ Manuscript received: January 29, 2019 \\ Revised version: March 7, 2019
}

\begin{abstract}
DruZHININ A., 2019. The sea factor in the spatial and socio-economic dynamics of today's Russia. Quaestiones Geographicae 38(2), Bogucki Wydawnictwo Naukowe, Poznań, pp. 91-100. 2 tables.

ABSTRACT: The World Ocean and, in particular, its resource potential have always had a dramatic effect on the progress and spatial organisation of humanity. Recently, the effect of the sea factor on the economy and the settlement system has increased amid globalisation, geoeconomic changes, increasing geopolitical turbulence, and the growing competition for resources. In this article, I attempt to assess the influence of the sea factor on the socioeconomic geography of the Russian Federation. A country with an extensive coastline and a vast inland area, Russia has territories that are very different in geographical terms. I pay special attention to the post-Soviet changes in the major components of the country's maritime economy: seaports, fishing industry, offshore production, recreation, etc. Another focus is the assessment of these industries' impact on the development of the coastal areas. I demonstrate the growing dependence between the maritime economy and the economic development of Russia's inland regions. I identify the key natural geographic, foreign economy, settlement-related, and geopolitical factors of the coastalisation of the economy, infrastructure, and population, observed in Russia today. This process is taking place in the Baltic, Black, and Caspian Sea areas, as well as in the Arctic and Pacific regions of the country. I conclude that Russia's integration into the system of multi-dimensional Eurasian partnerships (including the Belt and Road initiative) and the 'turn to the East' contribute to both the further 'marinisation' of Russian space and the differentiation of coastal zones by the level and rates of socio-economic development.
\end{abstract}

KeY wORDs: socio-economic dynamics, coastal zones, Russia, Eurasia, World Ocean, geopolitics, geo-economics

Corresponding author: Alexander Druzhinin, North Caucasus Research Institute of Economic and Social Problems, South Federal University, Bol'shaya Sadovaya Ulitsa, 105, 344006 Rostov-on-Don, Russia, e-mail: alexdru9@mail.ru

\section{Introduction}

The World Ocean affects different aspects of the lives of humans and society. Its effect is universal, although not ubiquitous in geographical

1 President of the Association of the Russian SocioEconomic Geographers (ARGO); Head of the North Caucasus Research Institute of Economic and Social Problems, South Federal University, Rostov-on-Don; Research Professor, I. Kant Baltic Federal University, Kaliningrad, Russia. terms. Science has discussed the sea factor for over a century. This factor is embodied in the visions of history as a series of 'maritime civilisations' (Mechnikov 1995), in the interpretations of centuries-long economic practices (according to Fernand Braudel (1995), the sea always meant wealth), and in various geopolitical models. The latter include the numerous attempts to emphasise the differences between the coastal and inland territories (Mackinder 1904) and to stress the influence of 'sea powers' on the world 
politics (Eberhardt 2013). Since the mid-20th century, the development of maritime transport and the growing consumption of the resources of the World Ocean (Slevich 1988) have turned 'all things maritime' into an integral element of human geography, which attracts special attention from scientists working in coastal countries. For instance, Polish geographers have considered the maritime economy components as a research priority since the 1960s (Leszczycki 1964), and they have made impressive progress in this field (Palmowski 2016). Similar processes took place in the USSR and are taking place in Russia. A significant national achievement is the development of the economic geography of the World Ocean (Salnikov 1984). Since the late 2000s, this research discipline has gained fresh momentum (Druzhinin 2016a). This process is in line with the global trend of the rampant coastalisation of population, economies, and infrastructure (Cori 1999; Turner 1996; Suárez Vivero 2005; Bowen 2006). 'Coastal fever' has gripped regional studies (McFadden 2007; Baklanov 2018).

Against the background of this global trend, Russia's position in the 'continent-ocean dichotomy' (Bezrukov 2008) is ambivalent. On the one hand, the history of the country is that of an exploration of the vast lands of Eurasia and of the development of controlling national centres, the major one being Moscow. On the other hand, Russia has been approaching the World Ocean and its coasts for almost five centuries. The 'sea factor' was the key to Russia's conquest of Siberia in the 17th century (Kaluczkov 2017) and the Far East in the 19th century (Zhivopisnaya Rossiya 1895). In the Russian Empire of the early 20th century, 13 of the 56 cities with a population of over 50,000 people were either coastal or contiguous with the estuaries of large navigable rivers. The most rapid development of the 'maritime segment' of the national economic and settlement systems was observed in the 1960s-1970s (Druzhinin 2016a).

Three oceans and 13 seas wash post-Soviet Russia's coasts. The country's maritime boundary is over 46 thousand $\mathrm{km}$ long, its offshore acreage is 4 million $\mathrm{km}^{2}$, and the area of the exclusive economic zone reaches 8.5 million $\mathrm{km}^{2}$. All this is giving the 'seaward shift' new determinants, impetus, and manifestations. The prevailing perception of Russia as an 'ocean of land', as a mostly continental space (Savitskiy 1997) with the major centres located far from sea coasts (Lappo 2012) should give way to the one taking into account the country's maritime features and the role of the sea factor in its spatial organisation and development. The purpose of the article is to analyse the dynamics of the maritime economy in post-Soviet Russia, to assess the impact of the 'maritime factor' on the settlement and spatial organisation of the economy (including the one concerning the integration processes in the format of 'Greater Eurasia'). The provisions and conclusions of the study were based on the methodology of system analysis, involving the consideration of the maritime economy to be a significant component and factor in the spatial development of Russia. The research methods include economic-statistical and spatial-temporal analysis using a vast array of data by Rosstat for 1989-2017.

\section{The post-Soviet dynamics of Russia's maritime economy: Key factors and trends}

After the disintegration of the USSR, its strong marine economy collapsed. Its capacities were privatised, and some of them came under the control of foreign owners and capital. Only eight out of 17 Soviet shipping facilities and 42 out of 67 seaports (most of them shallow-water) were now located within the borders of Russia (Alkhimenko 1992). Fifteen large port cities (with a population of over 100,000 people), including Baku, Odessa, Riga, Tallinn, Sevastopol, and others, became part of the independent states. In the early 1990s, the transformation-driven downturn reduced Russia's marine cargo traffic by two-thirds, although the global trend was opposite. Moreover, Russian ports handled slightly over $60 \%$ of this traffic (Soviet Maritime 2003). The country's fleet was being gradually forced out of the freight market, and Russia resumed the pre-revolutionary (pre-1917) practices when its imports and exports were carried by foreign ships. The national fish and shellfish capture production halved in the 1990s. The shipbuilding industry was in decline: by the end of the decade, only $17 \%$ of the capacities of national enterprises were in operation (Parfenov 1997). Fewer tourists were visiting popular sea resorts. 
Table 1 . The cargo handled by Russian seaports in 2013-2017, by catchment areas.

\begin{tabular}{|c|c|c|c|c|c|c|c|c|c|c|}
\hline \multirow[b]{2}{*}{ Catchment area } & \multicolumn{2}{|c|}{2013} & \multicolumn{2}{|c|}{2014} & \multicolumn{2}{|c|}{2015} & \multicolumn{2}{|c|}{2016} & \multicolumn{2}{|c|}{2017} \\
\hline & $\begin{array}{l}\text { Million } \\
\text { tonnes }\end{array}$ & $\%$ & $\begin{array}{l}\text { Million } \\
\text { tonnes }\end{array}$ & $\%$ & $\begin{array}{l}\text { Million } \\
\text { tonnes }\end{array}$ & $\%$ & $\begin{array}{l}\text { Million } \\
\text { tonnes }\end{array}$ & $\%$ & $\begin{array}{l}\text { Million } \\
\text { tonnes }\end{array}$ & $\%$ \\
\hline Baltic Sea & 215.8 & 36.7 & 223.4 & 35.8 & 230.7 & 34.1 & 236.6 & 33.0 & 247.5 & 31.4 \\
\hline Arctic Ocean & 46.2 & 7.8 & 35.0 & 5.6 & 35.4 & 5.2 & 49.7 & 7.0 & 74.2 & 9.4 \\
\hline Azov-Black Sea & 174.4 & 29.6 & 194.5 & 31.2 & 232.9 & 34.4 & 244.0 & 33.8 & 269.5 & 34.2 \\
\hline Caspian Sea & 7.8 & 1.3 & 7.9 & 1.3 & 6.7 & 1.0 & 6.1 & 0.8 & 3.9 & 0.5 \\
\hline Far Eastern & 144.8 & 24.6 & 162.5 & 26.1 & 171.0 & 25.3 & 185.5 & 25.7 & 191.7 & 24.5 \\
\hline National total & 589.0 & 100.0 & 623.4 & 100.0 & 676.7 & 100.0 & 721.9 & 100.0 & 786.8 & 100.0 \\
\hline
\end{tabular}

Source: own study based on the data from the Russian Association of Sea Commercial Ports.

Having lost a number of strategically important sections of the coast and having 'retreated' north-eastward, for almost a decade, Russia lost both its maritime ambitions and the opportunities to achieve them. ${ }^{2}$ Nevertheless, the country was becoming open to the world while obtaining a pronounced raw material specialisation. This, and the fuel prices soaring in the early 2000s, created a favourable climate for the restoration and development of the vital components of Russia's maritime economy.

Since the trend reversed in 1999, Russia has witnessed explosive growth in imports and exports, with sea traffic and pipelines accounting for over a half of them (Koncepciya 1997). Emphasis was placed on both increasing the capacities of the existing ports (Novorossiysk, Saint Petersburg, and others) and constructing new ones primarily in the Baltic (Ust-Luga, Primorsk). According to the Russian Associations of Sea Commercial Ports, the volume of cargo handled by Russian seaports grew twofold in 2000-2005 only, reaching 407 million tonnes (all the Soviet ports handled up to 280 million tonnes of import and export cargoes [Sea economic complex 2005]). The upward trend continued. The volume of cargo handled reached 526 million tonnes in 2010, 623 million in 2014, and 786.8 million in 2017. Note that, in the early 2000s, the port economy developed most rapidly in the Russian Baltic. However, the Baltic ports have been recently overtaken by their counterparts in the Azov-Black-Sea basin (Table 1 ). These changes coincided with the gradual change in the country's geoeconomic priorities:

The need to strengthen Russia's position as a marine power was first declared as such only in 2001, as part of the Maritime Doctrine of the Russian Federation until 2020, which was approved by the President. the EU accounted for almost $54 \%$ of Russia's international trade in $2008,40.5 \%$ in 2014 , and only $43.2 \%$ in the first half of 2018.

An important novelty in Russia's 'sea-intensive' goods and raw materials logistics was the construction of submarine pipelines (Blue Stream, Nord Stream, Turk Stream, and projected Nord Stream 2) for natural gas transport. The total maximum discharge of the pipelines is 157.5 billion $\mathrm{m}^{3}$ per year, which comprises $81 \%$ of Gazprom's 2017 gas sales to Europe (the former Soviet republics excluded). Among other things, the decision to construct underwater gas transport systems sought to reduce Russia's dependence on the transit countries (in particular, to avoid the recurring crises involving Ukraine and Belarus) and to minimise possible geopolitical risks. However, from the beginning of the 2000s, the ambitions of Russian companies were gradually shifting to the LNG market. Notably, since January 2018, the needs of the Russian exclave in the Baltic, the Kaliningrad region, have been covered by seaborne LNG.

According to the Federal Customs Service, fuel accounts for almost $65 \%$ of Russia's exports, metal makes up $10.1 \%$ of it and agricultural raw materials, primarily grain $5.2 \%$. This global raw materials specialisation encouraged Gazprom and other large businesses working in the field (Lukoil, Novatek, Rosneft, and others) to develop offshore oil and gas deposits. As mentioned above, Russia's offshore acreage is 4 million $\mathrm{km}^{2}$, whereas the area of its exclusive economic zones is approximately 8.5 million $\mathrm{km}^{2}$ (Sea economic complex 2005). Today, shelf exploration is carried out in the Black, Baltic, and Caspian Seas, and other waters. The seats of the largest projects are Sakhalin and Yamal (the new seaport facility of Sabett). The latter is located in the strategically 
important Arctic zone. ${ }^{3}$ In turn, all this contributes to growth in sea traffic and the active exploitation of the Northern Sea Route. Seven million tonnes of cargo were carried along the route in 1990. In 2000, this figure reduced 1.5-fold. In 2016, it reached the 'Soviet' levels once again and, in 2017, increased to 10.7 million tonnes per year).

In the mid-2000s, the negative trend reversed in the sea-fishing sector. Note that $75 \%$ of Russian fisheries operate in the Far East. In 1990, the total national capture production was at 7.9 million tonnes; in 2004, at 2.9 million tonnes (the absolute minimum); and, in 2011, at 8.3 million tonnes. Later, this figure ranged from 5.5 to 6.5 million tonnes. Russian marine bioresource came to be exploited by companies from across the world and thus included in transnational value chains. Most produce was sold, most ships were repaired, and most of the new fleet was bought beyond Russia's jurisdiction.

The recent decade has seen an upturn in Russian shipbuilding, primarily, in the construction of icebreakers, offshore platforms, and naval ships. In the past five years, the shipyards of Saint Petersburg, Severodvinsk, Kaliningrad, and Komsomolsk-on-Amur built 65 ships of different classes within the State Armaments Programme 2020. It is expected (Shepovalov 2018) that the programme will be completed only by $70-75 \%$.

As the Polish geographer Ryszard Domański stresses, the spatial organisation transformations are always more radical when they are a result of daring political and economic innovations and massive investment (Domański 1994: 10). In post-Soviet Russia, the overall market situation, the efforts of large businesses, and the state policy (consistent and successful, according to international experts (Radvanyi 2017)) made 'sea-intensive' logistics projects both a sine qua non and a driver of economic activity. The completion of these projects, offshore oil and gas development, marine bioresource exploration, the revitalisation of sea resorts, and the efforts to strengthen

The priorities of Arctic exploration are listed in the Framework for the state policy of the Russian Federation in the Arctic until 2020 and beyond (2008), the Strategy for the development of the Artic zone of the Russian Federation and for national security until 2020 (2013). The Arctic is in the focus of the revised Maritime Doctrine of the Russian Federation, which was signed by the President of the Russian Federation in 2015.
Russia's defence have created a background for restoring the integrity of the marine economy. Moreover, all this has boosted the socio-economic development of coastal regions and made them more attractive as places of residence.

\section{The coastalisation of Russia's population: The role of the sea factor}

Russia has a much lower population density than its neighbours do, and its transport and utility infrastructure is often patchy. All this pushes coastal settlement and economy systems closer to the sea. This is especially true for the Arctic zone, where the 'selective-indiscriminate' exploration of the North translated into erratic, sporadic urbanisation (Pilyasov 2016). Russia's coastal zone resembles a narrow discontinuous band. Almost 36,800 out of $41,000 \mathrm{~km}$ of Russia's maritime boundary belong to the Arctic and the Pacific. The environment of these sparsely occupied areas is harsh. The most prosperous coastal territories are those within the scope of influence of Saint Petersburg, Rostov-on-Don, Vladivostok, Kaliningrad, and other coastal cities with development agglomerations. Located either on the seacoast or in the estuaries of major navigable rivers, these cities have a pronounced marine element in their economies. It has been shown (Transgranichnoe 2017) that the effect of the sea factors extends as far as $100-150 \mathrm{~km}$ from the shoreline.

The demographic decline, which was observed in 1992-2012 and resumed in 2016, was caused by de-industrialisation and natural depopulation. This process affected all the coastal cities, including Saint Petersburg (its population was decreasing from 1992 to 2008), Rostov-on-Don (population decline in 1992-2001), Vladivostok (in 1993-2009), Arkhangelsk (in 1992-2007), Sochi (in 2000-2007), and others.

In the 1990s, the depopulation of Russia's coastal zone was aggravated by emigration from the northern, north-eastern, and eastern coastal regions of the country (the latter process is observed to this day). From Murmansk to Vladivostok and Yuzhno-Sakhalinsk, only four out of 34 Russian Arctic and Pacific cities have shown a positive demographic tendency. These are Yuzhno-Sakhalinsk, Naryan-Mar, Salekhard, 
Table 2. The distribution of coastal city population by macrozones (\%).

\begin{tabular}{|l|r|r|r|r|}
\hline \multicolumn{1}{|c|}{ Macrozone } & 1989 & 2002 & 2010 & 2017 \\
\hline Baltic & 41.2 & 42.2 & 42.5 & 43.2 \\
\hline Azov-Black Sea & 25.0 & 26.4 & 25.8 & 25.6 \\
\hline Barents-White Sea and Arctic & 11.7 & 9.6 & 8.9 & 8.5 \\
\hline Caspian & 7.7 & 9.4 & 10.6 & 11.2 \\
\hline Pacific & 14.4 & 12.4 & 12.2 & 11.5 \\
\hline
\end{tabular}

Source: own study based on the census and current statistics data.

and Artyom. The total demographic losses of the coastal cities of the Russian Arctic and the Far East from 1989 are estimated at 600,000 people, which is the population of the country's major Pacific city, Vladivostok.

Since the beginning of the 2000s, Russia has experienced the coastalisation of its population. However, this process was sporadic: the population of only 37 out of 74 Russian coastal cities increased in 2002-2018 (there are 1,112 cities and towns in the country).

The migration of the 'coastal' population of Russia towards the Baltic and the Caspian Sea area is accompanied by the following spatial trends (the statistics for Crimea, which became part of Russia in 2014, is taken into account in all the calculations).

1. The first trend is the continuing concentration of the country's population in the largest multifunction cities, which serve as regional capitals. This is in line with the overall national trend (Druzhinin 2013). This process is observed in Saint Petersburg (its population has increased by 530,000 people or $11.3 \%$ in the post-Soviet period), Rostov-on-Don ( 96,000 or $9.6 \%)$, Kaliningrad $(52,000$ or $13 \%)$, and some other cities.

2. The second trend is the 'gravitation' of the population towards the resorts of the Black Sea (Sochi, Anapa, Gelendzhik) and the SouthEast Baltic (Svetlogorsk and Zelenogradsk in the Kaliningrad region).

3. The third trend is the rapid population growth observed in the coastal towns performing a distinct function. These are the port town of Primorsk in the Leningrad region (a 15\% growth) and the naval towns of Severomorsk and Gadzhiev in the Murmansk region.

A positive demographic tendency is observed in large exporting centres: Naryan-Mar and Salekhard. This also applies to the Caspian cities of Dagestan, including Makhachkala, where the population increased by 400,000 people or 2.3fold in 1989-2017. However, in this city, the major driver of the population increase is a natural change. Overall, in the post-Soviet period, the total population of Russian coastal cities increased by $6.5 \%$ (or 832,700 people), having reached 13.7 million. Thus, coastal cities account for $12.6 \%$ of the country's urban population, as compared to $11.8 \%$ in 1989 . All this proves the significance of the sea factor for the settlement system dynamics. Coastaliation is characteristic of selected segments of the Russian shoreline only. The demographic growth localised in these areas spurs the economy and creates specific forms of the spatial organisation of society at the sea-land interface.

\section{The sea-land spatial organisation of today's Russia: Common formats and local features}

The sea factor has had an increasing effect on the spatial organisation of Russia. The explanation lies in the geographical position of the country and its key regions, the dynamics of marine industries, and the coastalisation of the major elements of the settlement system. This effect has numerous aspects.

The actual and potential effect of the sea factor is significant in the coastal macroregions of Russia: the South $(67 \%$ of the population live within $200 \mathrm{~km}$ of the coast) and the North-West (only $4 \%$ of the population within $200 \mathrm{~km}$ ). The dependence on the marine economy is even more pronounced in the North of Russia (the Arctic zone). This territory relies heavily on the pre-winter supply from the south and on the local companies' export. The largest coastal macroregion is Russia's Far East (Baklanov 1987). For a century, an important sea-land structure has been the Russian-promoted Northern Sea Route. The Route is essential for the systems of transport, communication, resources, industrial production, settlement, infrastructure, and defence. It started to play a more pronounced role following global climate change and the launch of operations at the Sabetta port facility on Yamal (the Yamal LNG project).

In the Russian Federation, marine economy industries are becoming gradually localised 
and major settlement and economic centres are moving towards seacoasts. As a result, 17 Russian regions can be classified as 'sea-oriented' (Sotsial'no-ekonomicheskoe 2016). According to my calculations, marine industries account for $4.4 \%$ of the gross domestic product. However, this proportion reaches $15 \%$ in the Kaliningrad, $25-30 \%$ in the Murmansk, and $65 \%$ in the Sakhalin regions. In the post-Soviet period, the Leningrad, Krasnodar, and Rostov regions (all of them classed as sea-oriented) have become both transport and development corridors (according to John Friedmann 1967). Since the 2000s, the expansion of port facilities has been accompanied by sea-driven reindustrialisation. Spurred by transboundary cooperation, this process affects the food industry and mechanical engineering. Fisheries, shipbuilding, ship repair, port logistics, mineral extraction, and car assembly companies are forming clusters (Transgranichnoe 2017). Clustering is most pronounced in the Saint Petersburg coastal region (Lachininskij 2016) and in the exclave of Kaliningrad. The latter region has many years' experience of working with both 'mainland' Russia and the neighbouring states (Fyodorov 2009).

The spatial characteristics of the Russian economy translate in an urgent need for both international communication channels and streamlined interaction between the marine and inland regional segments. Notably, Saint Petersburg, the Leningrad, and the Kaliningrad regions account for $9 \%$ and $18 \%$ of the national exports and imports respectively. Sixty-two out of eighty-five Russian regions do not border on seas. These territories are home to $75.8 \%$ of the national population, and they comprise $76.1 \%$ of the country's economy. Nevertheless, they are being 'pulled' towards the sea by specific structures - the hinterlands (zones of influence) of seaports.

Within port hinterlands, export-oriented territories actively cooperate with the coastal zone, which serves as the transit area. This especially applies to coal mining (coal from the Kuznetsk Basin is shipped from Murmansk, Ust-Luga, and the ports of South Russia), the oil industry, metallurgy, mineral fertiliser production, and timber harvesting. The explosive growth of Russia's grain exports (the volume of wheat sold abroad has increased tenfold over the past decade (Raj 2015)) activated similar processes in agriculture, which is primarily localised in the South of Russia, along its Azov and Black Sea coasts. Up to $90 \%$ of grain exports are handled by Black and Azov Sea ports. This has turned the Rostov and Krasnodar regions into the pivotal territory for grain production and grain exports. Similarly to grain businesses, large companies representing other Russia's export industries either invest in the construction of new port facilities or purchase stevedoring companies. SIBUR, NOVATEK, and Eurochem built their own transhipping facilities at Ust-Luga, Russia's largest Baltic port. Rosnet, Nornickel, and Lukoil have bought stevedoring firms. Such practices ensure stable port turnover and extend port hinterlands to hundreds and thousands of kilometres. For example, the eastern border of the influence zone of the country's largest port, Novorossiysk, coincides with the administrative boundary of Yakutia (Vardomskij 206). A similarly extensive hinterland is associated with Big Port Saint Petersburg (Transgranichnoe 2017).

The expansion of the hinterlands of the largest ports contributes to the agglomeration effects in both the economy and settlement. In the coastal zone of Russia, there are six large agglomerations, each with a population of over 500,000 people. Overall, there are 44 such structures across the country. The coastal agglomerations account for $85 \%$ of the population increase in the observed Russia's coastal cities over the post-Soviet period. The largest, economically and functionally diversified structure oriented to both the sea and inland regions is the Saint Petersburg agglomeration. Together with the Kaliningrad region, it comprises the central communicative space in the Russia-the West system. This space has become part of the integration processes taking place in the Baltic. Nevertheless, in today's geoeconomic situation, almost all segments of the country's marine periphery, which includes both border waters and coastal zones, are affected by sea-land transboundary regionalisation. This process is localised within the catchment areas of seas. The most rapid development of an international macroregion is observed in the Baltic Sea (Fedorov 2017). Another arena for integration is the Black Sea area (Dobranski 2013), where the settlement and economic structures are asymmetrical. The Turkish segment of the coastal zone is home to $70 \%$ of the population 
of all Black Sea cities, and the population of the Istanbul agglomeration has increased 2.3fold since 1990. The Russian coastal zone takes part in transboundary economic processes in the Sea of Okhotsk and the Sea of Japan areas (Tikhookeanskaya Rossiya 2008). The signing of a convention on the legal status of the sea (2018) gave a new boost to transboundary regionalisation in the Caspian area. So far, Russian coastal regions have been on the area's periphery in relation to the major latitudinal marine communications.

The marine (sea-land) components are growing in number. They are becoming both more visible in the spatial organisation of Russian society and more internationalised. This process is well in line with the geoeconomic and geopolitical changes in Eurasia.

\section{Prospects of the 'marinisation' of the Russian space in the context of the Big Eurasia project}

Over the past decades, the heterogeneous integration processes taking place in Eurasia (Eurointegration, the 'Turkish world' project, the Eurasian Economic Union, and others) have been accompanied by the demographic and economic potential of the continent moving eastward and south-eastward (Druzhinin 2018). This has a profound effect on the established geoeconomic landscape. In this context, China's Belt and Road Initiative, which was announced in 2013, is both an indicator of and a strategic vision for a new Eurasian reality (or the 'production of space' in the terminology of the distinguished theoretical geographer David Harvey 1972). Chinese geographers consider the initiative as a new horizon of globalisation (Liu 2015). This concept has been closely associated with the concept of Big Eurasia in Russia since 2015-2016. A multi-neighbourhood country (Trejvish 2009) bordering on Eurasian states with 'different parts of its vast heterogeneous body' (Granberg 2000: 311), Russia heavily and increasingly depends on the economic dynamics of other major European and Asian states and the availability of their markets to Russia's businesses. According to the data of the Federal Customs Service for January-September 2018,
Eurasian states account for 94\% of Russia's bilateral trade, and the countries that share a land border with Russia for $30.6 \%$. An important factor for the development of the Russian marine economy is that Big Eurasia (if considered as the whole continent, which Halford Mackinder luckily labelled the World Island (1904)) has a pronounced sea component. The absolute majority of the largest Eurasian economies (29 out of 30) are coastal in geographical terms. The coastal zones of Eurasia are home to a significant proportion of the global alpha cities (21 out of 49). Overall, 34 megalopolises are located in Eurasia and on its islands. Out of the 40 largest seaports (with a turnover of over million tonnes), 27 are Eurasian. Eleven of them are situated in China. In the Eurasian context, Russia's further 'marinisation' will be promoted by:

- the growing demand from the leading Eurasian states for Russia's resources (including offshore ones) and transport routes (primarily, the Northern Sea Route);

- growing geopolitical turbulence and the need for Russia and its corporations to build 'flexible' logistic schemes and economic partnerships with the major power centres of the continent (the EU, China, India, and others), based on a developed system of seaports;

- attractive prospects for the localisation of export-oriented and import-substitution businesses in the leading coastal zones of Russia (the Baltic coast, the Krasnodar region, the South of Primorye, etc.);

- the strategic need for Russia to become more visible in the Arctic and the Asian-Pacific.

In building a multidimensional foreign policy (Druzhinin 2016 b), Russia will have to turn to the sea, to develop port, logistics, and industrial facilities, to expand port hinterlands through investment projects, and to participate in the formation of land-sea complexes along its maritime boundaries. All this will require the launch of new infrastructural projects from the Baltic to the Pacific (Shuper 2016). The necessary steps are included in the Transport strategy of the Russian Federation until 2030, which has been in effect since 2008. In 2014, the mitigation of the transport isolation of the Russian exclave of Kaliningrad became a separate geostrategic objective. The solution includes the development of ferry connections from Kaliningrad to Ust-Luga and 
Saint-Petersburg, the reconstruction of the key industries of Crimea's marine economy (recreation, shipbuilding, fishing), and the ensuring of stable electricity and water supply to the peninsula.

\section{Conclusion}

Today, Russia is at a geoeconomic and geopolitical crossroads. Thus, the significance of the World Ocean, and its communication lines, resources, and strategic military potential is increasing. The past two decades have seen the revitalisation of the key components of the country's marine economy: seaports, fishing, tourism, and recreation. At the same time, the effect of the sea factor on the coastal territories, the spatial organisation of society, and its economic and settlement subsystems is increasing. These processes manifest themselves in the 'gravitation' of people towards the major coastal agglomerations, the development of modern economic structures (such as transboundary clusters) in coastal zones, and the close connection between the marine and inland segments of the Russian economy. The Big Eurasia and Trans-Eurasia projects, Russia's participation in them as a raw materials and transit territory, and the inclusion of the country's coastal regions into various transboundary partnerships are inseparable from the further 'marinisation' of the Russian socio-economic space. The latter, in its turn, requires careful attention to the economic, social, environmental, and geopolitical effects of maritime activities. A considerable contribution can be made within the 'Socio-economic geography of the World Ocean discipline', which has been relaunched and developed by several national university centres: Vladivostok, Kaliningrad, Rostov-on-Don, Saint Petersburg, and Simferopol.

\section{Acknowledgements}

The study was prepared with the support of the Russian Science Foundation, project no. 1918-00005 "Eurasian Vector of Russian Marine Economy: Regional Economy Perspective" and 18-010-00015 "Models, effects, strategies and mechanisms of the inclusion of the western borderline of Russia into the system of horizontal interregional economic relations in the context of the Greater Eurasia".

\section{References}

Alkhimenko A.P., 1992. Issues of the regional organisation of marine nature management and management of marine complexes. In: Alkhimenko A.P. (ed.), Regional'naya organizatsiya i upravlenie morekhozyaistvennymi kompleksami strany. Abstracts of the Vth Conference on Geography and Oceanography, St. Petersburg: 3-8 (in Russ.).

Baklanov P.Ya., 1987. Formation of aqua-territorial economic complexes and areas in the Far East. In: Primorskie regiony: geograficheskie $i$ sotsial'no-ekonomicheskie problemy razvitiya (Primorye regions: geographical and socio-economic development problems). Vladivostok: 84-93 (in Russ.).

Baklanov P.Ya., 2018. Marine spatial planning: Theoretical aspects. Baltic Region 10(2): 76-85.

Bezrukov L.A., 2008. Kontinental'no-okeanicheskaya dikhotomiya $v$ mezhdunarodnom i regional'nom razvitii (Continental-oceanic dichotomy in international and regional development). Novosibirsk: 286 (In Russ.).

Bowen B., Frankic A., Davis M., 2006. Human development and resources use in the coastal zone: Influences on human health. Oceanography 19(2): 62-71.

Brodel F., 2006. Material naya civilizaciya, e`konomika i kapitalizm, XV-XVIII vv. (Material civilization, Economics and capitalism, XV-XVIII centuries) T. 2. Igry` obmena. Moskva: Izd-vo «Ves` Mir»: 672 (in Russ.).

Cori B., 1999. Spatial dynamics of Mediterranean coastal regions. Journal of Coastal Conservation 5: 105-112.

Dobranski S., 2013. Formirovanie Chernomorskogo soobshhestva (Formation of the black sea community). Polis. Politicheskie issledovaniya 1: 177-181 (in Russ.).

Domański R., 1994. Spatial organization in the process of transition from a centrally planned to a market economy. Geographia Polonica 1: 5-12.

Druzhinin A.G., 2013. Spatial possibilities and barriers of the postindustrial development of a regional metropolis (the case study of Rostov-on-Don). Regional Research of Russia 3(4): 356-361.

Druzhinin A.G., 2016. «Maritime» component in the Russian human geography: Traditions and novations. Izvestiya Rossiiskaya Akademii Nauk, Seriya Geograficheskaya 6: 7-16 (in Russ.).

Druzhinin A., 2016. Russia in modern Eurasia: The vision of a Russian geographer. Quaestiones Geographicae 35(3). Bogucki Wydawnictwo Naukowe, Poznań: 31-39.

Druzhinin A.G., Dong Y., 2018. One Belt - One Road initiative: A window of opportunity for Russia's western border regions. Baltic Region 2: 39-55.

Eberhardt P., 2013. Koncepcja nawalizmu Alfreda Thayera Mahana (Conception of navalism by Alfred Thayer Mahan). Przeglad Geograficzny 85(4): 629-654.

Feodorov G.M., Korneevecz V.S., 2009. Transgranichny`e regiony' $v$ ierarxicheskoj sisteme regionov: sistemny` $j$ podxod (Cross-border regions in the hierarchical system of regions: A systematic approach). Baltijskij region 2: 32-41 (in Russ.)

Fedorov G.M., Mikhailov A.S., Kuznetsova T.Yu., 2017. The influence of the sea on the economic development and settlement structure in the Baltic Sea Region. Baltic Region 9(2): 7-27. 
Friedmann J., 1967. A general theory of polarized development. Ford Foundation. Urban and Regional Development Advisory Program in Chile: 473.

Granberg A.G., 2000. Osnovy regional noj e`konomiki (The foundations of the regional economy). M.: Gosudarstvenny ${ }^{j}$ universitet «Vy`sshaya shkola e`konomiki»: 400 (in Russ.)

Harvey D., 1972. Revolutionary and counter revolutionary theory in geography and the problem of ghetto formation. Antipode 4(2): 1-13.

Kaluczkov V.N., 2017. Russkij Sever i Sibir`: istorikoi kul turno-geograficheskie aspekty` vzaimodejstviya (Russian North and Siberia: Historical, cultural and geographical aspects of interaction). Social'no-e konomicheskaya geografiya. Vestnik ARGO 5: 148-156. (in Russ.).

Koncepciya federal`noj celevoj programmy" «Mirovoj okean» (The concept of the Federal target program «World ocean»). Rossijskaya gazeta, January 28, 1997 (in Russ.).

Lachininskij S.S., Lachininskij A.S., Semenova I.V., 2016. Geoe`konomicheskij faktor $\mathrm{v}$ formirovanii prostranstvennoj struktury`Sankt-Peterburgskogo primorskogo regiona (Geo-economic factor in the formation of the spatial structure of the St. Petersburg seaside region). Izvestiya RGO 148(2): 52-67 (in Russ.).

Lappo G.M., 2012. Goroda Rossii. Vzglyad geografa (Cities of Russia. The opinion of the geographer). M.: Novy $j$ xronograf: 504.

Leszczycki S., 1964. Research problems in Polish geography. Geographia Polonica 1: 7-22.

Liu W.D., 2015. Scientific understanding of the Belt and Road Initiative of China and related research themes. Progress in Geography 35(5): 538-544.

Mackinder H.J., 1904. The geographical pivot of history. The Geographical Journal 23: 421-37.

McFadden L., 2007. Governing coastal spaces: The case of disappearing science in integrated coastal zone management. Coastal Management 35(4): 429-443.

Martinez M.L., Intralawana A., Vazquezb G., Perez-Maqueo O., Sutton P., Landgrave R., 2007. The coasts of our world: Ecological, economic and social importance. Ecological Economics 63: 254-272.

Mechnikov L.I., 1995. Tsivilizatsiya i velikie istoricheskie reki (Civilization and the great historical rivers). M.: Pangeya: 461 (in Russ.).

Palmowski T., 2016. Morskie uwarunkowania ładu przestrzennego (Marine determinants of spatial order). In: Chaberek-Karwacka G. (ed.), Wspótczesne uwarunkowania procesów zarzadzania prestrzenia w Polsce (Contemporary determinants of sptial management processes in Poland). Wydawnictwo Uniwersytetu Gdańskiego: 119-137.

Parfenov A., 1997. Rol' transportnykh kommunikatsiy i portovykh kompleksov v razvitii ekonomiki Rossii (The role of transport communications and port facilities in the development of the Russian economy). Morskie porty 2: 34-47 (in Russ.).

Pilyasov A.N., 2016. Goroda-bazy`Arkticheskogo frontira (Base cities of the Arctic frontier). Voprosy` geografii. Sb. 141. In: Kotlyakov V.M., Streleczkij V.N., Glezer O.B., Safronov S.G. (eds), Problemy regional nogo razvitiya Rossii. M.: izdatel`skij dom «Kodeks»: 503-528 (in Russ.).

Radvanyi J., 2017. Quand Vladimir Poutine se fait géographe... Hérodote. Géopolitique de la Russie 166-167: 113132.
Raj V.V., 2015. Zernovoj sektor Rossii v usloviyax VTO (Grain sector of Russia in the WTO). Problemy prognozirovaniya 1: 76-83 (in Russ.).

Salnikov S.S., 1984. Ekonomicheskaya geografiya okeana novoe perspektivnoe napravlenie ekonomicheskoy i sotsial'noy geografii (The economic geography of the ocean - a new perspective direction of economic and social geography). Sovetskaya geografiya (Soviet geography). L.: Nauka: 231-242 (in Russ.).

Savitskiy P.N., 1997. Kontinent-Okean (Rossiya i mirovoy rynok) Continent - Ocean (Russia and the world market). Kontinent-Evraziya. M.: Agraf: 398-418 (in Russ.).

Sea economic complex of Russia, 2005. Saint-Petersburg: 273 (in Russ.).

Slavin S.V., 1961. Promy 'shlennoe i transportnoe osvoenie Severa SSSR (Industrial and transport development of the North of the USSR). M.: E`konomiizdat: 302 (in Russ.).

Shepovalov M., 2018. Predvaritel'ny`e itogi Gosudarstvennoj programmy`vooruzhenij-2020 v chasti voennogo korablestroeniya (Preliminary results of the state program of arms-2020 in the part of the military shipbuilding). E`ksport vooruzhenij 1:34-49 (in Russ.).

Shuper V.A., 2016. Evrazijskoe budushhee Rossii v svete cheredovaniya integracionny` $x$ i dezintegracionny` $x$ ciklov (Eurasian future of Russia in the light of alternation of integration and disintegration cycles). Baltijskij region 8(4): 7-17 (in Russ.).

Slevich S.B., 1988. Okean, resursy i khozyaistvo (Ocean, resources and economy). Leningrad: 246 (in Russ.).

Sotsial'no-ekonomicheskoe razvitie primorskikh territoriy Evropeyskoy chasti Rossii: faktory, trendy, modeli (Socio-economic development of coastal areas of the European part of Russia: Factors, trends, models), 2016. Druzhinin A.G.(ed.), Yuzhnyy federal'nyy universitet. Izdatel'stvo Yuzhnogo federal'nogo universiteta, Rostov-na-Donu: 236 (in Russ.).

Soviet Maritime Newsletter, 2003: 138.

Suárez Vivero J.L. de, Rodríguez Mateos J.C., 2005. Coastal crisis: The failure of coastal management in the Spanish mediterranean region. Coastal Management 33(2): 197-214.

Tikhookeanskaya Rossiya: stranitsy proshlogo, nastoyashchego, budushchego (Pacific Russia: The last page, present, future), 2008. Baklanov P.Ya. (academic ed. RAN), Vladivostok, Dal'nauka: 216 (in Russ.).

Transgranichnoe klasteroobrazovanie v primorskix zonax Evropejskoj chasti Rossii: faktory', modeli, e’konomicheskie i e kisticheskie e 'ffekty' (Cross-border cluster formation in the coastal zones of the European part of Russia: Factors, models, economic and economic effects), 2017. Druzhinin A.G. (ed.), Izdatel`stvo Yuzhnogo federal`nogo universiteta, Rostov-na-Donu: 421 (in Russ.).

Trejvish A.I., 2009. Gorod, rajon, strana i mir. Razvitie Rossii glazami stranoveda (City, district, country and world. Development of Russia through the eyes of a country historian). M.: Novy j xronograf: 372 (in Russ.).

Turner R.K., Subak S., Adger W.N., 1996. Pressures, trends, and impacts in coastal zones: Interactions between socioeconomic and natural systems. Environmental Management 20(2): 159-173.

Vardomskij L.B., 2016. Ob Aziatskom vektore transformacii e`konomicheskogo prostranstva Rossii (About the Asian vector of transformation of economic space of Russia). Voprosy` geografii. Sb. 141. In: Kotlyakov V.M., Streleczkij V.N., Glezer O.B., Safronov S.G. (eds), Problemy 
regional nogo razvitiya Rossii. M.: izdatel`skij dom «Kodeks»: 539-555 (in Russ.).

Zhivopisnaya Rossiya. Otechestvo nashe v ego zemel'nom, istoricheskom, plemennom, ekonomicheskom i bytovom znachenii (Picturesque Russia. Home of his land, historic, tribal, economic and domestic value), 1895. In: Semenov P.P. (ed.), T.12. Vostochnye okrainy Rossii. Primorskaya i Amurskaya oblasti (Eastern border regions of Russia. Maritime and Amur regions). M.: 493 (in Russ.). 